\title{
TEACHERS AND SOCIAL COHESION IN THE GLOBAL SOUTH: EXPANDING THE NOTION OF EDUCATION QUALITY
}

\author{
Yusuf Sayed \\ University of Sussex \\ Email:Y.Sayed@sussex.ac.uk \\ Centre for International Teacher Education (CITE) \\ Email: sayedy@cput.ac.za
}

\section{Azeem Badroodien \\ Cape Peninsula University of Technology \\ Email: badroodiena@cput.ac.za}

\section{INTRODUCTION ${ }^{1}$}

The second decade of the $21^{\text {st }}$ century has been largely characterised by ever-widening inequalities within and between countries, global economic crises, conflict, and climate change. Concern about this is evident in the Sustainable Development Goals (SDGs) agreed upon in September 2015. The SDGs arguably lay a foundation in both the Global North and the Global South for a renewed and ambitious development framework that tackles poverty and inequality, promotes social and economic inclusion, addresses the universal challenge of climate change, and focuses directly on issues of equity and access to quality education.

Countries and organisations across the world, in engaging with this framework and reflecting on the various agreed (SDG) goals for 2030, have however struggled to comprehensively define the challenges attached to each of the above goals - especially the latter. What is meant by equitable and inclusive quality education for all? On the one hand, an estimated 250 million children across the world are still 'not learning even

1 We hereby acknowledge the very special efforts and contribution of Dr Rada Jancic Mogliacci in bringing this special edition together.

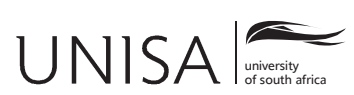

Education as Change

Volume 20 | Number 3 | 2016 | pp. 1-14

www.educationaschange.co.za

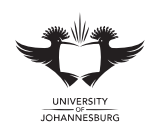

DOI: http://dx.doi.org/10.17159/1947-9417/2016/1975 Print ISSN 1682-3206 | Online 1947-9417

(C) 2016 The Author(s) 
basic literacy and numeracy skills, let alone the further skills they need to get decent work and lead fulfilling lives' (UNESCO 2014). On the other hand, where children do access education provision, the quality of the provision has often been directly related to their economic status. Invariably 'the well-off tend to attend good schools and universities, mostly privately funded, and the poor attend inadequate, mostly publicly funded facilities' (United Nations Development Programme 2013). This is particularly the case in developing countries, and suggests that a central driver in transforming human development prospects in these countries into the next period would need to be tied to the provision of greater access to 'high-quality education'.

Furthermore, embedded in debates on quality education as countries and organisations move towards the development of the 2030 SDG agenda, has been a particular connection made with 'good teachers' and their role in helping achieve the targets set. UNESCO (2014) asserts for example that it is 'good teachers' that 'close the gap between poor and good quality education by maximising the benefits of learning in every classroom for every child'. After home background, teachers and teaching are seen as fundamental to learner performance (Vegas et al. 2012; Sayed \& Ahmed 2014). Similarly Barber and Mourshed (2009) argue that the quality of education cannot rise above the level of its teaching although more accurately it is teaching.

In the Global South however, debates about quality education and teacher education remain steeped in deeper concerns about exclusion, injustice, inequality, and deeprooted patterns of violence and conflict stemming from institutionalised dispossession and marginalisation. For many, the quest for quality education is firmly tied to larger historical developments and dilemmas that include continuities and discontinuities that have been entrenched across diverse historical contexts.

As such, and as this special edition shows, the awareness of the need to influence quality teaching and learning through teacher education has elicited a variety of responses in various countries in the Global South, with many adopting a particular approach to social cohesion and social justice as a way of engaging with how the ambitious policy intent of the SDGs may best be realised.

For the special edition, to foster a comparative perspective of different approaches and challenges within the Global South, there is a specific focus on how teachers are able to mitigate inequality and reduce violence through the promotion of peace and social cohesion in different contexts. The aim is to identify and highlight measures and processes in the different contexts that speak to the role of teachers in the provision of education and teaching that contribute to social justice.

The special edition consists of 11 articles and one book review organised in the following way. The first article opens with a proposed framework for social cohesion that foregrounds social justice and then provides a comparative country perspective of teachers as agents of social cohesion in four different country contexts to examine this. The two articles that follow then explore how teacher governance reforms could promote social cohesion, focusing on the country studies of South Africa and Pakistan 
respectively. The next two articles examine how textbooks and curricula in Columbia, South Africa, and South Sudan reflect and construct particular versions of the past and visions of the future; versions that shape the ways in which tolerance and social cohesion can (or cannot) be promoted in the classroom. Four articles then look at the ways in which teacher pedagogy could promote social cohesion in South African classrooms. The special edition concludes with two articles on political conflict and peacebuilding in Rwanda and Lebanon and sketches the particular difficulties experienced in addressing the structural inequalities that hindered social cohesion initiatives aimed at achieving social justice.

\section{CONCEPTUALISING EDUCATION, SOCIAL COHESION, AND TEACHERS FOR SOCIAL JUSTICE}

Education in most modern societies is arguably the primary medium through which social solidarity is promoted and where key values and social norms are generated and developed (Durkheim 1964; Tawil \& Harley 2004). Furthermore, it is through education that engagements with past injustices, historical memory, transitional justice processes, and better communal interaction in the social arena are thought about and tackled, often bringing different communities together to encourage processes of forgiveness and healing. This is especially the case in societies with histories of direct conflict (Hamber 2007).

Conversely, violent conflict within societies, especially when combined with political mobilisation, remains the inevitable outcome when inequalities based on gender, disability, ethnicity, race, religion, class, educational status and geographical location, among others, are allowed to fester and endure (Stewart 2008). This is especially true when structural inequalities limit the distribution of educational opportunities for all citizens, and foster conflict and fragility instead (Smith et al. 2011).

For this reason, equality of access to good quality education is said to be a key contributor to peacebuilding and poverty reduction. That is because it arguably restores trust in state functions (Smith et al. 2011) and integrates students as productive members of society. Good quality education reduces the likelihood of conflict and promotes social cohesion and forms of social justice by discouraging, when conflict erupts, a reliance (or threat) on force, violence, or fighting - whether that be broader societal upheaval, individualised disputes between different communities or persons, or discords based on race, gender, or social class. Degu (2005), Schwartz (2010), and Davies (2010) have shown for example that in contexts where a significant proportion of youth participated in armed conflict, good quality educational opportunities helped reintegrate them as productive members of society, which in turn hopefully reduced the likelihood of them taking up arms again.

Within such an approach to quality education the role of social cohesion is to bring communities together, and help build solidarity, trust, inclusion, social capital, and peace 
amongst them (Organization for Economic Cooperation and Development [OECD] 2011; the World Bank Forum 2015; the United Nations Development Programme [UNDP] 2014; the UN Department of Economic and Social Affairs [UN DESA] 2015). Social cohesion is understood then as the loose bonds that bring individuals together and that influence their behaviour; it equates to building solidarity and trust, inclusion, social capital, and reducing poverty in society; it is promoted when a sense of belonging and a willingness to help are inculcated amongst citizens; and it is distilled when heterogeneous groups have a sense of common belonging, participation, inclusion, recognition, and legitimacy (Chan, To \& Chan 2006).

The key idea that permeates this special edition is that systemic inequality is a key driver of social injustice and that the creation of more just and cohesive societies plausibly requires the dismantling of such systemic inequality. This requires analytical and historical attention to the way in which systemic inequalities emerge, and the social mechanisms that are applied to reduce such inequalities. Historically, it is teachers that have played the foremost role in nation building, identity construction, and peace and reconciliation (Sayed et al. 2016a). It is what teachers do, with what learning resources they have, that shape what children and young people learn, and what kinds of learner identities emerge in relation to both their skills for employment and for peacebuilding (Barrett et al. 2006). Davies (2010) asserts that teachers' agency is particularly crucial 'in developing values of mutual respect and tolerance in post-war contexts characterized by persisting division and mistrust'.

As agents of social justice and cohesion, the special edition explores the ways that teachers exercise the above agency given the constraints of their diverse contexts. Via careful scholarly consideration, the special edition explores the potential of teachers to disrupt inherited patterns of exclusion and injustice. A number of articles draw on the work of Nancy Fraser $(1998 ; 2005 ; 2008)$ to tease out a particular conception of social cohesion as a form of social justice. They suggest that the struggle for redistribution, recognition, representation, and reconciliation by those who have been historically marginalised and dispossessed can bring about greater levels of social justice in a global context marked by increasing inequalities between and within countries. This, they argue, is particularly necessary in a global world that is contextually shaped by a resurgence of neo-liberal political solutions (as seen through structural adjustment and financial austerity measures) to perceived education crises. As such, the articles in the special edition examine the role of teachers as agents of social cohesion at both theoretical and empirical levels.

\section{A COMPARATIVE PERSPECTIVE ON TEACHERS AS AGENTS OF SOCIAL COHESION}

Novelli and Sayed's article entitled 'Teachers as Agents of Sustainable Peace, Social Cohesion and Development: Theory, Practice \& Evidence' opens the special edition 
by proposing a framework for social cohesion that foregrounds social justice. Drawing on the work of Nancy Fraser, they argue that social cohesion as a form of social justice needs to uphold representation, recognition, redistribution and reconciliation both in education in general, and particularly in relation to teacher agency. Drawing on rich fieldwork data collected between 2014-2016 in Myanmar, Pakistan, South Africa, and Uganda as part of an ESRC-DFID and UNICEF grant, Novelli and Sayed point to the complex and contradictory roles that teachers play in fostering sustainable peace and development and in social cohesion initiatives. They note that in both the ESRC-DFID grant on Engaging Teachers as Agents of Peacebuilding and the UNICEF grant that focused on Peacebuilding, Education, and Advocacy efforts at changing teacher governance, teacher policy, textbooks and curricula and teacher professional development in the four countries had a number of strengths and weaknesses that were contingent on the contextualised nature of the different interventions. As such, Novelli and Sayed argue that in order to activate teacher agency for social cohesion, and lay a foundation for durable and just peace, education policies and programmes not only need to firmly contextualise interventions in local and historical settings but also need to actively address structural inequities in their attached societies, and in education in particular.

\section{TEACHER GOVERNANCE}

The next two articles in the edition on Pakistan and South Africa offer comparative insights into teacher governance reforms specifically, especially their contribution to the promotion of social cohesion in the two countries. Both articles argue that in societies emerging from the long shadows of conflicted pasts teachers need to be deployed to areas of need and that policy mechanisms need to ensure that societies and school communities have greater trust in them. Teachers can be both victims and perpetrators of violence and conflict and thus government teacher governance measures need to firmly address and monitor the ways teachers are publicly perceived and approached. Both articles show that government-instituted teacher governance measures, whilst mostly well intentioned, are often frustrated by poor, weak and ineffective policy implementation with little capacity to deliver, monitor, or be accountable. The authors suggest that to understand teacher governance greater attention thus needs to be paid to the actions of actors at sub-national and local levels who are the frontline implementers of policy.

Salmon and Sayed's article entitled 'Teacher Governance Reforms and Social Cohesion in South Africa: From Intention to Reality' traces the trajectory of postapartheid teacher governance reforms as a way of understanding how, on the one hand, teacher recruitment and deployment policies sought to promote equity, and how, on the other, regulatory bodies for teachers like the South African Council of Educators (SACE) and teacher codes of conduct focused on promoting trust. Salmon 
and Sayed assert that accountability is the most fundamental ingredient in ensuring equitable recruitment and deployment and the building of teacher trust, and that this is not helped by undifferentiated policy frameworks that weakly account for differing contextual realities and persistent inequalities. To show this, the article draws on and examines data collected for an ESRC-DFID grant on Engaging Teachers as Agents of Peacebuilding on three teacher governance interventions in South Africa, namely, the post-provisioning norms and standards (PPNs), the Funza Lushaka Bursary Programme (FLBP), and the South African Council of Educators (SACE) as the body responsible for ensuring compliance with the Code of Professional Ethics. The article observes that while the interventions have bold and progressive policy intentions, these are not realised in practice because of the decentralised nature of the South African education system. Salmon and Sayed suggest that as local actors at provincial, district, and school levels mediate national policy intentions there is a need to better balance central national directives with local participation and involvement. This is particularly necessary if teachers are to be empowered to destabilise existing and inherited patterns of educational privilege and school inequities.

In exploring teacher governance in Pakistan, Halai and Durrani's article entitled 'Teacher Governance Factors and Social Cohesion: Insights from Pakistan' reviews key reforms initiated after 9/11 in Pakistan - efforts that sought to improve equity on the basis of gender, language, ethnicity, religion, and special needs by initiating a merit and needs-based policy on teacher recruitment. Also tied to the ESRC-DFID grant on Engaging Teachers as Agents of Peacebuilding and the UNICEF-funded Peacebuilding, Education, and Advocacy grant, the article illustrates how equity-focused teacher governance measures in Pakistan are hindered by persistent implementation challenges, and how progressive policy intentions mainly go unrealised due to a lack of capacity and micro-political factors at the local level. Halai and Durrani suggest a more targeted approach in Pakistan, with stronger forms of monitoring and accountability provided to instantiate teacher governance reforms that promote social cohesion.

\section{TEACHERS, CURRICULUM AND TEXTBOOKS}

As noted above, teachers need teacher governance policies that are conceptually sound, well structured, and effectively implemented if dynamic and agential forms of trust and equity are to be constituted in school classrooms. Notably, to effect social cohesion, teachers also need textbooks and curricula that frame what they are able to enact pedagogically in their classrooms. Textbooks and curricula have a key role to play as potential peacebuilding devices and have the capacity to address past and present injustices more directly, promote the recognition of difference, and create opportunities for equitable participation in classrooms.

In many cases however, as the experiences of South Africa and other countries show, textbooks and curricula fail to fundamentally address these issues of tolerance and 
respect and often limit the abilities and capacities of teachers to promote social cohesion in their classrooms. As the following two articles in the special edition illustrate, the ways in which narratives of conflicted pasts are captured in History textbooks and curricula used in Colombia, South Africa, and South Sudan often construct and shape how future societies are envisioned.

Rodríguez-Gómez, Foulds and Sayed's article entitled 'Representations of Violence in Social Science Textbooks: Rethinking Opportunities for Peacebuilding in The Colombian and South African Post-Conflict Scenarios' analyses how violence is represented in Social Studies textbooks in Colombia and South Africa, with a particular focus on historical narratives. Rodríguez-Gómez, Foulds and Sayed reflect how the treatment of violence and national conflict in textbooks in two countries emerging from violent pasts that scar the present usefully illustrates the ways in which social cohesion is approached and understood. Worryingly, they observe that in many ways textbooks in Columbia and South Africa do not substantively deal with conflict, and that the partial and punctuated ways in which historical narratives are explained fail to confront the structural dimensions of violence in the two countries. This consequently inhibits the ways in which viable, just, and durable national cohesion can be approached. Their article suggests that curriculum developers, textbook writers, policy makers, and international agencies need to pay more careful attention to how textbooks and curricula are discursively constructed, their potential to shape how structural violence is dealt with, and the complex interrelationships between individual actors and broader societal structures when trying to produce curriculum mechanisms that seek to promote peace. They caution that textbooks and curricula may in fact end up reproducing the very conditions that they seek to remediate.

This cautionary note is also evident in Skårås and Breidlid's article entitled 'Teaching the Violent Past in Secondary Schools in Newly Independent South Sudan'. They analyse the History curriculum and textbooks in South Sudan, focusing on secondary students' written work, observations, and interviews with teachers and students, and argue that failures to confront the past in textbooks and curricula (in reality efforts are primarily focused on historically erasing the past) could sow the seeds for even further on-going conflict. The article observes that the current national historical narrative embedded in textbooks (and consequently the teaching project), representing 'the north as the enemy', advances a singular version of the past that totalises and harmonises South Sudanese national identify by excluding 'the other'. Skårås and Breidlid argue that suppressing representations of conflicts manifested along ethnic lines limits the abilities of students in South Sudan to confront and deal with the historic drivers of conflict in their country drivers that remain at play in the contemporary period. Paradoxically, they note that the pedagogical ideal of teaching multiple narratives could also fuel conflict and disunity in classrooms and the wider society, and that historical accuracy and presentations of the past may be a necessary expense when pursuing a unified collective identity at times of strife. 


\section{TEACHERS AND PEDAGOGY}

Four articles in the special edition speak to teacher pedagogy aimed at promoting social cohesion in South African classrooms. They highlight the diverse ways in which teachers enact pedagogy for social cohesion and how professional development could enhance teaching practices. They point to the need for a contextualised account of teacher pedagogies focused on social cohesion across urban and rural contexts, across wealth divides, and across racial and gender divides.

Cappy's article entitled 'Shifting the Future? Teachers as Agents of Social Change in South African Secondary Schools' draws on an ethnographic study of rural and township schools in Kwa-Zulu Natal to illuminate how teachers translate teaching for transformation in diverse classroom contexts, and the ways in which they encourage their students to reflect critically upon their own lives. Drawing on Freire's (1970) theory of critical pedagogy, Cappy observes that teachers tend to view their roles as agents of change as limited to encouraging respect, morality, and racial reconciliation amongst students, with references to inequality and the ways in which it is produced being remarkably absent from their teaching. Their pedagogic imagination, she argues, whilst committed to change, does not extend to collective action for transformation and instead privileges individualised notions of personal responsibility and commitment to a better future. In her study, by not speaking directly to social justice, the progressive pedagogies of teachers in classrooms mainly lead to students engaging in what Cappy terms 'moral translation', namely reworking and mediating classroom lessons into basic ideas about how they should behave as moral human beings. As such, their pedagogical approach to social cohesion is highly individualised, with personal responsibility and action seen as the foundation for redressing historic and structural patterns of inequality. Cappy asserts that there is a need for a more thoroughgoing application of Freirean pedagogy, where teaching practices are reworked in ways that allow teachers and students to engage in real critical reflections that inspire actions, especially those that promote transformation based on social justice.

Vandeyar and Swart's article entitled 'Educational Change: A Case for a "Pedagogy of Compassion"" also draws inspiration from Freire's idea of critical pedagogy. Based on a study of a single classroom that arguably exemplified best teaching practices, Vandeyar and Swart advance the concept of 'pedagogies of compassion' which are characterised by teaching practices that tackle and confront apartheid legacies, seek to raise the critical consciousness of students, and are grounded in teacher reflexivity and introspection. They assert that if founded on compassion and humanity, teacher pedagogies can transcend apartheid legacies of inequality and segregation and work towards developing meaningful post-conflict environments. Vandeyar and Swart conclude that if teachers are to function as transformative intellectuals in classroom settings, where they actively confront the past in order to realise a post-racial future, it will require them to change fundamentally their understandings of what they do and to adapt their current roles. 
Jancic Mogliacci, Raanhuis and Howell's article entitled 'Supporting Teachers in Becoming Agents of Social Cohesion: Professional Development in Post-Apartheid South Africa' draws on a study of a Continuing Professional Development (CPD) programme that is offered to teachers in South African classrooms. The 'Teaching Respect for All' programme is offered by the Institute for Justice and Reconciliation (IJR) and has trained over 500 teachers in South Africa to deal with discrimination in the classroom. Drawing on multiple methods of inquiry, the article notes some positive gains for teachers emerging form the programme, particularly in relation to changing their teaching practices. Jancic Mogliacci, Raanhuis and Howell conclude however that changing teachers' beliefs and pedagogies for social cohesion is a long-term objective that requires continuing professional development that extends beyond workshop settings. They observe that shifting teachers' beliefs and conceptual understandings cannot be attained through once-off training programmes and that it instead requires sustained support at the school and classroom level. Their observations throw into sharp relief the South African reality that many CPD programmes for social cohesion are mainly offered by NGOs with insecure sources of funding, and call attention to the need for embedding such programmes in the policies and practices of national and provincial departments of education.

The final article on teacher pedagogy is provided by Francis and Reygan and is entitled ' "Let's See If It Won't Go Away by Itself". LGBT Microaggressions among Teachers in South Africa'. The article explores the subtle forms of discrimination (which the authors call 'microaggressions') towards lesbian, gay, bisexual and transgender (LGBT) people in South Africa. Drawing on in-depth interview data with 25 Life Orientation teachers in the Free State Province of South Africa, the article chronicles the biases and prejudices perpetuated by teachers, pointing to dominant heterosexual normativities that determine general teacher practices and behaviours. Francis and Reygan show how teachers struggle to realise basic forms of social cohesion in their school contexts and how progressive commitments enshrined in the South African Constitution are not realised in practice. Concluding that schools can only be considered truly inclusive spaces if schools are firmly committed to the mitigation and eradication of current disriminations, microaggressions, and 'systemic heterosexism' in classrooms, Francis and Reygan provide key suggestions for improving current policy, curriculum and teacher education provision.

\section{ENSURING SOCIAL COHESION AND STABILITY}

The special edition concludes with two articles on peacebuilding and social cohesion in and through education in Lebanon and Rwanda.

Rubagiza, Umutoni and Kaleeba's article entitled 'Teachers as Agents of Change: Promoting Peacebuilding and Social Cohesion in Schools in Rwanda' explores how teachers are positioned to promote peacebuilding and social cohesion in Rwandan 
schools in the aftermath of the 1994 genocide against the Tutsi population. Rwanda presents an interesting case of post-conflict social cohesion as, similar to some of the other articles in this edition, national unity is privileged in favour of deeply examining the historical drivers of conflict. Drawing on data from semi-structured interviews, focus-group discussions, questionnaires and classroom observations, this article notes, arguably, the presence of a 'positive' policy environment for social cohesion in Rwanda. Yet, behind the surface of an enabling policy narrative of unity and social cohesion are several inter-related factors that expose the fault lines of the Rwandan peace consensus as it relates to teachers' positioning as agents of change and transformation. In particular, it highlights challenges relating to the professional development of teachers, teacher management, and the school environment, all of which have the potential to undermine efforts to build sustainable peace and social cohesion.

The last article is by Maha Shuayb and is entitled 'Education for Social Cohesion Attempts in Lebanon: Reflections on the 1994 and 2010 Reforms'. The article explores political conflict in Lebanon in the 1990s and examines education policies, and specifically teacher education policies, that sought to promote social cohesion and justice in Lebanon after the civil war. Given the conflict-ridden nature of the society, the article sketches the particular difficulties that hindered the extent to which structural inequalities could be addressed. First providing a descriptive mapping of education policy reform in Lebanon, Shuayb then utilises the concepts of redistribution, representation, reconciliation and redistribution to analyse whether a social justice approach to social cohesion could have been better embedded in policy change. Noting key failures in the 1994 and 2010 education policy reforms to address structural inequalities in society, the article concludes that policy reforms that privilege a narrow and particular form of nationalism, a shared memory of the past, and reduces social cohesion to merely overcoming religious intolerance, are unlikely to promote durable forms of social justice.

\section{REALISING SOCIALLY JUST SOCIAL COHESION}

Collectively the 11 articles in the special edition cover a range of diverse Global South country contexts, including Colombia, Lebanon, Myanmar, Pakistan, Rwanda, South Africa, South Sudan and Uganda. The edition addresses several aspects of teachers' work and identifies some of the conditions and factors that impact on their agency to promote social cohesion and peacebuilding in multiple contexts. Several articles highlight in particular the extent to which ambitious policy intentions with regard to social cohesion are not realised in practice due to a lack of adequate theorisation, and a lack of capacity to implement and monitor policy and hold different constituencies accountable.

All the articles in the edition throw into sharp relief a need for a form of social cohesion that addresses fundamental drivers of conflict in societies where systemic and historical forms of inequality invariably thwart policy intentions intent on building 
cohesive societies. Divides based on race, social class, religion, or gender can only be bridged, they argue, if larger inequities in society are addressed and are accompanied by social cohesion initiatives that focus on generating feelings of trust, a common sense of belonging, and a willingness to cooperate with others.

Indeed, what many of the articles illustrate in the special edition is that the provision of good quality education in most modern societies is contingent on teachers actively promoting in their classrooms cohesive nation building, multiple identity construction opportunities, and sustainable peace, solidarity, and reconciliation practices. Both inside and outside school classrooms, teachers and quality teaching are fundamental pre-requisites for the generation of democracy, peace, the reduction of conflict, the building of social cohesion, and the upholding of national and individual identities for diverse contexts. These articles confirm that lasting and durable peace and the building of societal institutions require that schools consistently work as civic institutions and teachers as agents of social cohesion. As Maria Montessori notes, 'Establishing lasting peace is in the work of education; all politics can do is keep us out of war (cited in Abuelaish 2012).

They further confirm that if the primary goal of social cohesion is to develop bonds that bring individuals together and influence their behaviour (Shuayb 2012), then the key challenge of education policies is to simultaneously address the micro issues of teacher and student needs and the macro-level challenge of tackling the social, cultural, and political conditions that contribute to unequal distributions within society. Social cohesion initiatives can only provide social meaning and respect for all citizens when education policies ensure the kinds of participation that places everyone on par with each other as full partners in social interaction (Fraser 2005).

In the above regard, several articles in the edition caution that in tackling fragmentation and disunity the extent to which individuals and groups are invested in different sets of control, privilege, and domination need to be directly confronted. The strong refrain to the idea of nation, national identity, and national pride in curricula, in textbooks, and in teaching therefore may be an understandable response to social fragmentation, but can often only further deepen inequalities and divisions that then create further conflict.

A similar caution emerges from the articles on teacher pedagogy in the edition. While each offers a promising pathway for teacher practice that promotes social cohesion, there remains a glaring absence of what exactly pedagogies of social cohesion (whether critical pedagogies, pedagogies of compassion, or pedagogies of disruption) may mean in practice in diverse classrooms shaped differently by inequities of class, race, religion, gender and location. How do teachers enact such pedagogies in contexts where learning attainment in languages and mathematics are privileged and where curricula frameworks delegitimise inequities of class, race, religion, gender and location or represent them very narrowly? To this end, the articles in the special edition bring to the fore a need for more robust, rigorous and empirically grounded accounts of 
what pedagogies of social cohesion may look like in multiple and differing classroom contexts. They highlight the pressing need for contextualised and clear understandings of what pedagogical processes could generate quality learning in schools to effect social solidarity and change.

This also applies to how teacher agency is understood with regard to teachers working with students in creative and dynamic ways (Fenstermacher \& Richardson 2005). Currently, policy texts tend to reduce teacher agency into a variety of audit trails that underplay their ability to enact generative learning in classrooms with their students (Robertson 2012). Teacher agency is not a realistic possibility when the multiple and conflicting demands placed on teachers in various environments focus very narrowly on accountability measures. Social cohesion initiatives need to acknowledge how the roles and lives of teachers are firmly interconnected within the broader networks of relationships and structures in which they participate, and recognise that teachers can only play productive roles within these networks of relationships if the education policies and practices that define their everyday lives are better problematised.

The special edition demonstrates that in most societies emerging from conflict and with vastly differing drivers of inequity, bold and strong national policies normally focus on forging national unity in and through education. To this end, some conclusions emerging from the special edition as well as from other emerging research (Sayed \& Novelli 2016; Sayed et al. 2016b) suggest a number of tentative ways forward, as noted below.

Sayed et al. (2016b) specifically suggest several necessary but not sufficient conditions to realise social cohesion for social justice. These include political will reflected 'in leadership that places transformative social cohesion at the heart of system-wide reform focused on improving education quality. Such leadership needs to work across government departments...to develop proactive strategies of education redistribution in favour of the marginalised' (Sayed et al. 2016b, 323). It also requires shared consensus and participation leading to the "creation of a robust policy framework that includes a detailed and adequately funded plan for the implementation of a range of actions that address the issues that inhibit teacher agency' (Sayed et al. 2016b, 323). Moreover, it requires mutual trust and binding behaviours in which individuals and groups 'hold each other to account for agreed actions'. It also relies on the

aggregate capacity of the system to manage and monitor. Aggregate system capacity rests on the knowledge, skills, and dispositions of actors, which include national, provincial, and district officials, school leaders and teachers, and school governing body members. The propensity to act and to implement requires targeted and focused professional development programmes that empower these actors. (Sayed et al. 2016b, 324)

In conclusion, social cohesion founded on equity requires a collective societal vision and undertaking that is founded on social justice. In relation to education, this requires a national and global education agenda that places quality education at its core. In this 
regard, quality education needs to have a strong social justice orientation that does not delegitimise the affective and 'soft' aspects of education in favour of a narrow instrumentalism that privileges a focus on numeracy and literacy for economic growth. The real risk to the ambitions of the 2030 global education agenda is a hollowing out of the very concerns and aspects that make societies peaceful, stable, and equitable.

\section{ACKNOWLEDGMENT}

We would like to thank the ESRC-DFID for a research grant for the project Engaging Teachers in Peacebuilding in Postconflict Contexts: Rwanda and South Africa (PI: Yusuf Sayed) on which many articles in this special edition are based. However, the views expressed in this article reflect that of the authors and not that of the funders.

\section{REFERENCES}

Abuelaish, I. 2012. I lost my daughters in Gaza last time: Surely the bloodshed has to end? The Guardian, 7 November 2012. Retrieved from: https://www.theguardian.com/commentisfree/2012/nov/17/ izzeldin-abuelaish-plea-for-peace-gaza-israel (accessed 2 October 2016).

Barber, M. and M. Mourshed. 2009. Shaping the future: How good education systems can become great in the decade ahead. Report on the International Education Roundtable, 7 July 2009. Singapore: McKinsey \& Co.

Barrett, A.M., R. Chawla-Duggan, J. Lowe, J. Nikel and E. Ukpo. 2006. Review of the international literature on the concept of quality in education. Bristol: EdQual.

Chan, J., H.P. To and E. Chan. 2006. Reconsidering social cohesion: Developing a definition and analytical framework for empirical research. Social Indicators Research 75(2): 273-302.

Davies, L. 2010. The different faces of education in conflict. Development 53(4): 491-497.

Degu, W.A. 2005. Reforming education. In Postconflict development: Meeting new challenges. Edited by G. Junne and W. Verkoren. Boulder: Lynne Rienner.

Durkheim, E. 1964. The division of labor in society. New York: The Free Press.

Fenstermacher, G. and V. Richardson. 2005. On making determinations of quality in teaching. The Teachers College Record 107(1): 186-213.

Fraser, N. 1995. From redistribution to recognition? Dilemmas of justice in a 'post-socialist' age. New Left Review 1(212): 68-93.

Fraser, N. 2005. Reframing justice in a globalizing world. New Left Review 36: 69-88.

Fraser, N. 2008. Scales of justice: Reimagining political space in a globalizing world. Cambridge: Polity Press.

Glewwe, P., N. Ilias and M. Kremer. 2010. Teacher incentives. American Economic Journal: Applied Economics 2(3): 1-25.

Hamber, B. 2007. Forgiveness and reconciliation: Paradise lost or pragmatism? Peace and Conflict 13(1): 115-125. 
Novelli, M., M. Lopes Cardozo and A. Smith. 2015. A theoretical framework for analysing the contribution of education to sustainable peacebuilding: 4Rs in conflict-affected contexts. Retrieved from: http://learningforpeace.unicef.org/wpcontent/uploads/2015/05/TheoreticalFramework- Jan15.pdf (accessed 15 January 2016).

Robertson, S.L. 2012. Placing teachers in global governance agendas. Comparative Education Review 56(4): 584-607.

Sayed, Y. and M. Novelli. 2016. The role of teachers in peacebuilding and social cohesion: A synthesis report of South Africa, Uganda, Pakistan and Myanmar case studies. Research Consortium Education and Peacebuilding, University of Sussex.

Sayed, Y., A. Badroodien, T. Salmon and Z. McDonald. 2016a. Social cohesion and initial teacher education in South Africa. Educational Research for Social Change (ERSC) 5(1): 54-69.

Sayed, Y., A. Badroodien, Z. McDonald, T. Salmon, L. Balie, T. De Kock, A. Hanaya, W. SkirhotteKriel, J. Gaston and K. Foulds. 2016b. Teachers and youth as agents of social cohesion in South Africa. Cape Town: Centre for International Teacher Education.

Sayed, Y. and R. Ahmed. 2015. Education quality, and teaching and learning in the post-2015 education agenda. International Journal of Educational Development 40: 330-338.

Schwartz. 2010. Youth and post-conflict reconstruction: Agents of change. Washington DC: United States Bureau of Peace Press.

Shuayb, M., ed. 2012. Rethinking education for social cohesion: International case studies. Basingstoke: Palgrave Macmillan.

Smith, A., E. McCandless, J. Paulson and W. Wheaton. 2011. The role of education in peacebuilding: Literature review. New York: UNICEF.

Tawil, S. and A. Harley. 2004. Education, conflict, and social cohesion. Geneva: UNESCO, International Bureau of Education.

UN DESA. 2015. Transforming our world: The 2030 agenda for sustainable development. A/ RES/70/1. Paris: United Nations Department of Economic and Social Affairs.

UNESCO-IIEP. 2006. Guidebook for planning education in emergencies and reconstruction. Paris: UNESCO International Institute for Educational Planning.

UNESCO. 2014. Teaching and learning: Achieving quality for all. Paris: UNESCO.

United Nations Development Plan (UNDP). 2013. The human development report. The rise of the South: Human progress in a diverse world. New York: United Nations Development Programme.

United Nations Development Plan (UNDP). 2014. Human development report 2014. Sustaining human progress: Reducing vulnerabilities and building resilience. Retrieved from: http:/hdr. undp.org/en/2014-report (accessed 14 November 2016).

Vegas, E., A. Ganimian and A. Jaimovich. 2012. Learning from the best: Improving learning through effective teacher policies. Washington DC: World Bank.

World Education Forum. 2015. Incheon declaration: Education 2030 - Towards inclusive and equitable quality education and lifelong learning for all. Paris: UNESCO. 